\author{
大阪府立成人病せンター内科 \\ 北村次男中川実子堀内成人。乾久 朗
}

\title{
HEREDITARY PANCREATIC LITHIASIS
}

Tsugio Kitamura, Naruto Horiuchi, Fumiko Nakagawa and Hisaaki Inui

The Center for Adult Diseases, Osaka

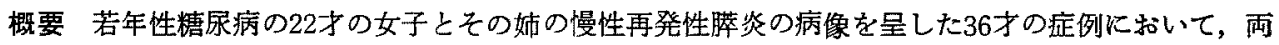
者とも腹部単純X線写真で明らかな膵石を認めた。第 1 例は18才で糖尿病を発症し, 第 2 例は10才こ ろより腹痛を自覚している。両例ともにアルュールは领まず，その他に膵石の発生と関係があると考 えられる腹部外傷などの既往もない，以上の事実よりこれらの症例は，遺伝性膵炎 $\rightarrow$ 遗伝性脺石症と 診断してよいと考えられる．わが国の脺石症の報告はすでに 120例以上になるが，家族性のものは， わずかに 1 組にすぎず，遺伝性と考えてよい症例は未だその報告をみない，本症例は著者の検討し得 た文献ではかが国における初めての報告例である。
\end{abstract}

はじめに

わが国でも，膵石または膵の石灰化の報告例が 120例をこえるようになつだ、その病態は各例各 様であるが，その成因または生成機構についても ようやく論議されるようになつて来た。睟石の成 生機構は勿論それ汪ど明らがされていない，し かし，その発生に密接な関係のあるるのとして， アルュールの過领, 内分泌腺ことに副甲状腺機能 元進，遺伝性の萃炎などがあげられている．現在 までのわが国の膵石症または膵の石灰化の報告例 では，家族性といえる例としてわずか一組の兄弟 があるのみである2)。その例も，その年令，およ び大酒家であつたといらことから考えて遺伀性と は考えられない。すなわら，わが国では遺伝性脺 石症と考学られる例の報告はまたみられない，今 回，遺伝性と考皇てよい一組の症例を経験した。 すなわち，若年性糖尿病の妹之慢性再発性膵炎の

〔昭和44年12月 8 日受稿〕

本論文要旨性第68回内科学会近畿地方会に扎いて哞 表した。

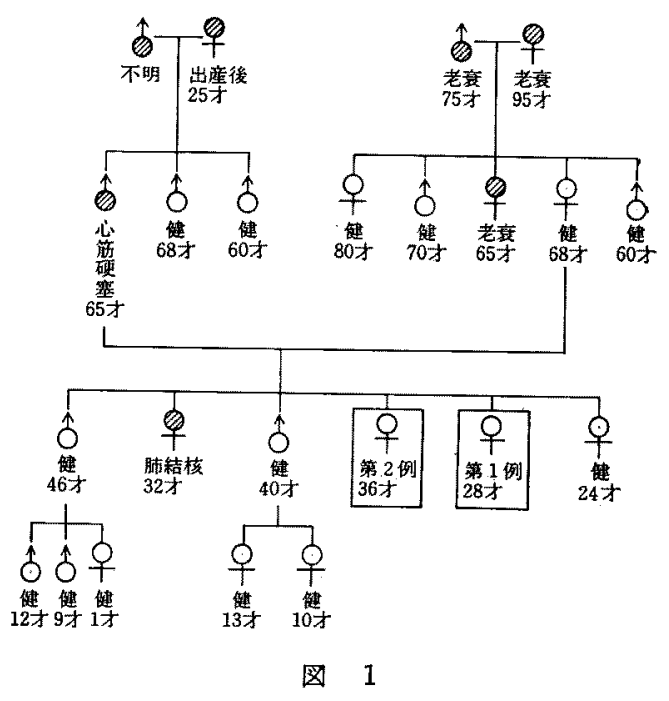

臨床像を示した姉の症例の腹部 X線像で，明かな 膵石を認めた。

症例 1.22 才（ 5 年前）の女店員である。家族 歴は図 1 のごとく本報告の 2 例以外にはとくに膵 炎または糖层病を疑わせるような例はない。 
既往に著患なし、酒, 㖶草はのまず, 性病は否 定している. 月経は17才で初潮をみたが，以来 2 回の月経発来をみたのみである.

現病歴：18才ころより多食にもかかわらず体 重の減少が認められた。すなわち，それまで $50 \mathrm{~kg}$ あつたものが $41 \mathrm{~kg} に$ 減少した. 診断の結果, 糖尿病 として入院, 3 カ月間インスリン治療をうけて退 院した. 2 年後の $20 才 の$ 時, ふたたびロ渴出現, 体重減少をみ, 再度 3 カ月間入院治療をうけてい る. その後外来治療をらけていたが, 腰痛, 頭 痛, 胸痛, 上腹部膨満感, 手のしびれ, 足蹠の刺 すような痛みなどが出没していた，昭和38年 4 月 入院. 食欲は普通, 睡眠は良好, 便通は $2 \sim 3$ 日 に 1 回であつた.

現症：身長 $150 \mathrm{~cm}$, 体重 $49 \mathrm{~kg}$, 栄養やや不 良, 皮膚怙よび可視粘膜正常, 脈拍分時68で整， 緊張良, 頭, 顔, 頝, 胸, 腹, 背および四肢に著 変を認めず. 血圧 $112 / 74 \mathrm{~mm} \mathrm{Hg}$. 検査成績 : 尿, 蛋白 (土), 糖 (卅), アセトン体 (土), 沈椬に 著見なし、屎，潜血反応ベンチジン（一，虫卵 (一). 末梢血, 赤血球 483 万，血色素 $89 \%$, 色 素指数 0.92 , 白血球 5,200 , 白血球分類 核指数 2.15 , 好中球 $69 \%$ （I 9\%，II 40\%，III 20\%, IV $0 \%$, 好酸球 $6 \%$, 好塩基球 $1 \%$, 単球 $3 \%$, リンパ球 $21 \%$ ，プラスマ細胞 $0 \%$. 赤沈 1 時間值 $15 \mathrm{~mm}$. 肝機能検査 総蛋白 $7.4 \mathrm{~g} / \mathrm{dl}, \mathrm{A} / \mathrm{G} 1.5$, $\mathrm{TTT} 1 \mathrm{u}, \mathrm{CCF} 24 \mathrm{~h}(一), コ ハ ゙ ル ト \mathrm{R}_{2(3)}$, 黄疸 指数 5 , B S P (45分值) $2 \%$. プロトロンビン 時間 $92 \%$. 血清蛋白分画 (チセリウス法) アル ブミン53\%，グロプリン $47 \%(\alpha 10 \%, \beta 17 \%$, $\gamma 20 \%$ ). 血清酵素GOT $62 \mathrm{u}, \mathrm{GPT} 47 \mathrm{u}$, alk-P-ase

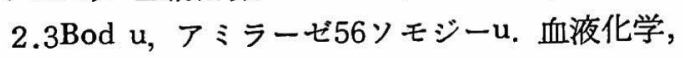
総コレステロール $200 \mathrm{mg} / \mathrm{dlNa} 145 \mathrm{mEq} / l \mathrm{~K} 4.9$ $\mathrm{mEq} / l, \mathrm{Cl} 96 \mathrm{mEq} / l, \mathrm{Ca} 9.2 \mathrm{mg} / \mathrm{dl}$. 腎機能は P S P (15分値) $41 \%$.ブドウ糖50 g 経口負荷試験, 血糖打よび尿糖は前 $282 \mathrm{mg} / \mathrm{dl}$ と $5.0 \%, 1$ 時間後 582 $\mathrm{mg} / \mathrm{dl}$ と $10.0 \% ， 2$ 時間後 $456 \mathrm{mg} / \mathrm{dl}$ と $15.0 \% ， 3$ 時 間後 $378 \mathrm{mg} / \mathrm{dl}$ と $10.0 \%$ でる. BMR $3.2 \%, \mathrm{P}$ B I $8.2 \gamma / \mathrm{dl}, \mathrm{VMA} 3.2 \mathrm{mg} / \mathrm{day}$, 尿ステロイ

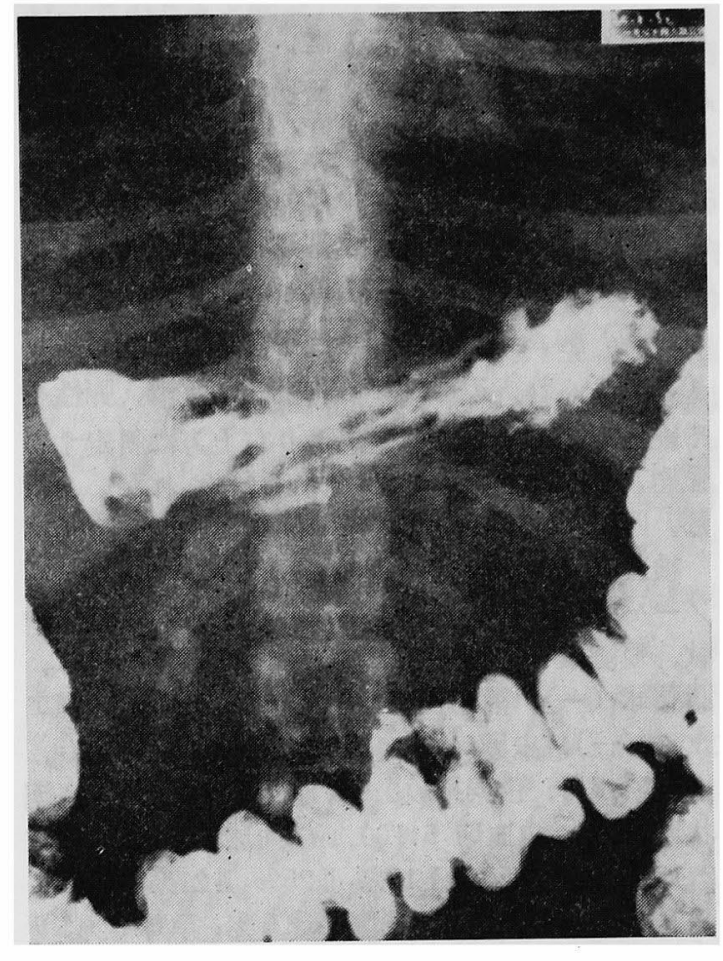

目 2

ド, 17-KS $4.4 \mathrm{mg} / \mathrm{day}, 17-\mathrm{OHCS} 7.6 \mathrm{mg} / \mathrm{day}$, トルコ鞍に異常をみとめず. 胸部X線像に著変な し. 眼底にも異常をみとめない. 消化管X線検査 で胃, 十二指腸, 大腸に異常を認めず。膵蔵部に 一致して広範な多数の結石の存在が認められた (第 2 図).な拈,本例の糖尿病の経過にかんしては すでに他泉にのべているのでここにはふれない。

症例 2.36才の女事務員である.

既往歴は，図1のごとくであり，症例 1 が本例 の8才年下の妹にあたる。

現病歴では, 20才の時, 肺浸潤の診断をうけて 治療をうけたことがある，酒，煙草はやはりのま ず, 性病は否定している. 月経順調である.

現病歴：10才ごろより時々腹痛があつた. 20 オごろ上腹部痛が強く 5 カ月間入院したことがあ る. 31才, 顔, 手足の浮腫感があつた. 当時血圧 が少し高いとのことであつた. 33才ごろから左背 の鈍痛のため整形外科を受診したことるある.こ の頃より, 微熱, 倦怠感, 頭重感, 上腹部膨満 
感，食欲不振などが出没していた。昭和44年 1 月 入院, 食欲はやや不良で, 便通は 1 日に $1 \sim 2$ 回 であつた．睡眠は良好。

現症：身長 $147 \mathrm{~cm}$, 体重 $46 \mathrm{~kg}$. 栄養やや不 良, 皮唐拉よび可視粘膜正常, 脈拍分時 96 , 整調 緊張良. 頭に著変なし, 眼球が少し突出気味であ る. 頝, 胸, 著変なし. 腹は平坦で肝を肋骨弓下 0.5 横指ふれ, 辺縁は鋭く, 表面は平滑, 弾性や や硬，圧痛はない，㑪上部より左上方に斜走する 腫瘤ようの抵抗をられた。脾，腎はふれない。背 部，四肢に著変なし．血圧 $168 / 92$.

検査成績： 尿, 蛋白 (一), 糖 (一), ウロビリ ノーゲン正常, 沈椬に著変なし. 屎, 褐色, やや 軟, 残渣なし, 粘液 $( \pm)$, 血液 $(-)$, 膿 $(-)$, 脂肪球 (一), 潜血反応, ベンチジン $(+)$, グア ヤク (一), 虫卵 (一). 末梢血, 赤血球 415 万, 血色素 $76 \%$, 色素指数0.91, 血小板 286,000 , 網 状球 $4 \%$, 白血球 6,100 , 白血球分類, 核指数 2.12 , 好中球 $65 \%$ ( I $17 \%$, II 25\%, II 21\%, IV 2\%, $\mathrm{V} 0 \%$ ), 好酸球 $3 \%$, 好塩基球 $0 \%$, 単球 $6 \%$, 》 ンパ球 $26 \%$ ，プラスマ細胞 $0 \%$. 赤沈 1 時間值10 $\mathrm{mm}$. 血液型 $\mathrm{O}$ 型, $\mathrm{Rh}(+)$. 血清梅毒反応, 口反 応(一), ガラス板法 (一). 肝機能検査 ; 総蛋白 $6.9 \mathrm{~g} / \mathrm{dl}, \mathrm{A} / \mathrm{G} 1.0$, クンケル $4 \mathrm{u}$, ユバルト $\mathrm{R}_{3}$, 血 清蛋白分画 (セルローズ・アセテー・膜法), アル

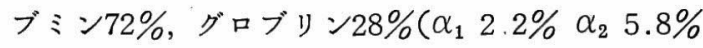
$\beta 7.9 \%, \gamma 12.1 \%)$. 血清酵素GOT $42 \mathrm{u}, \mathrm{GPT} 27 \mathrm{u}$ LDH 200u, alk-P-ase 3.3 Bodu, LAP13lu, アミ ラーゼは次の如くであつた.

\begin{tabular}{r|c|c}
\multicolumn{2}{c}{ 表 1} \\
\hline \multicolumn{1}{c|}{ 年 月 日 } & $\begin{array}{c}\text { 血清 } \\
\text { (Somogyi) u }\end{array}$ & $\begin{array}{c}\text { 尿 } \\
\text { (Wohlgemuth) } \mathrm{u}\end{array}$ \\
\hline 昭和43年 9月12日 & 83 & 16 \\
\hline 10月18日 & 96 & $\vdots$ \\
\hline 昭和44年 1 月23日 & 663 & \\
\hline 2 月21日 & 72 & 4 \\
\hline 3月 7 日 & 68 & 16 \\
\hline 3 月13日 & 95 &
\end{tabular}

血液化学, コレステロール $149 \mathrm{mg} / \mathrm{dl}, \mathrm{Na} 140$ $\mathrm{mEq} / l, \quad \mathrm{~K} 4.2 \mathrm{mEq} / l, \quad \mathrm{Cl} 108 \mathrm{mEq} / l, \quad \mathrm{Ca} 4.6$ $\mathrm{mEq} / l$, 無機 $\mathrm{P} 3.1 \mathrm{mg} / \mathrm{dl}$, 尿素 $\mathrm{N} 15 \mathrm{mg} / \mathrm{dl}$, ブドウ 糖50 g 経口負荷試験, 血糖拈よび尿糖は前 $77 \mathrm{mg} / \mathrm{dl}$ と(-)，1 時間後 $188 \mathrm{mg} / \mathrm{dl}$ と< $0.3 \% ， 2$ 時間後
$63 \mathrm{mg} / \mathrm{dl}$ と< $0.3 \%, 3$ 時間後 $63 \mathrm{mg} / \mathrm{dl}$ と（一）であ る. パンクレオザイミン・セクレチン試験, セク レチン注射後 1 時間の液量 $21 \mathrm{ml}$ ，七クレチン注射 後の最高重炭酸塩濃度は $27 \mathrm{mEq} / l$, 七クレチン注 射後 1 時間の重炭酸塩総排出量は $0.474 \mathrm{mEq}$, パ ンクレオザイミン注射後80分の総排出量は15,995 mg glucose (ソモジー法)と 3 因子とも低下してい

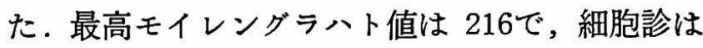
P C II であつた. 血清アミラーゼ反応は前 663 ソ モジーu，セクレチン注射後 2 時間で 215 ソモシ $-\mathrm{u}, 4$ 時間後 $219 \mathrm{u}$ であつた. Ca静注法による副

\begin{tabular}{|c|c|c|c|}
\hline & & $\mathrm{Ca}$ & $\mathrm{P}$ \\
\hline \multirow[t]{4}{*}{ 血 清 } & 前 & $4.7 \mathrm{mEq} / l$ & $2.7 \mathrm{mg} / \mathrm{dl}$ \\
\hline & 直後 & 4.6 " & 2.2 / \\
\hline & 4時間後 & 4.6 II & 3.4 \\
\hline & 20 時間後 & 4.6 "I & 2.8 \\
\hline \multirow[t]{2}{*}{ 尿 } & 対照尿 & $6.1 \mathrm{mEq} / l$ & $0.37 \mathrm{~g} / \mathrm{day}$ \\
\hline & 負荷後尿 & $6.4 \mathrm{II}$ & $0.32 \mathrm{II}$ \\
\hline
\end{tabular}

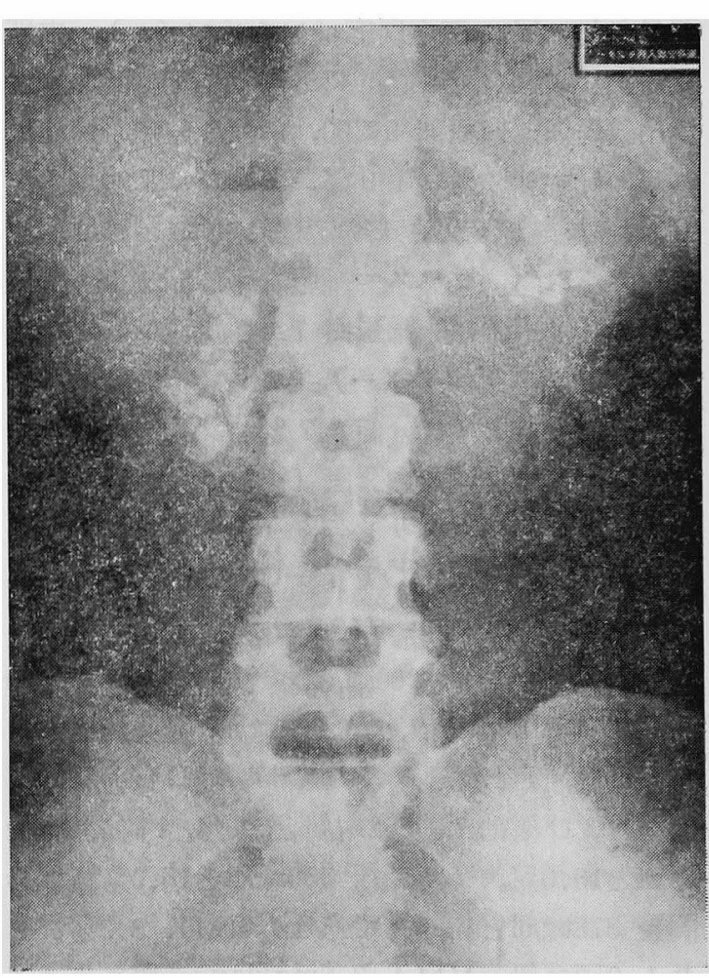

図 3 
甲状線機能検查は表 2 のごとく正常であつた．胸 部X線写真に著変なく心電図では S T の軽い低下 をみとめている。眼底に異常をみとめず，十二指 腸 X線検查上著変なく，明らかな脺石を第 3 図の 如くにみとめた。

\section{考案}

慢性膵炎の晚期の像として，糖尿病，脂肪性 下痢，それに，脺の石灰化の三つがあげられてい る。膵石症は慢性再発性膵炎の約 $40 \%$ Kみとめら れるといらいくつかの報告がある。すなわち，慢 性膵炎の腹部単純撮影では $17 \%$, 剖検で摘出し た膆のX線検查では 0〜8\%にそれぞれ見られる という報告もあり，剖検時の発見頻度は 0.028 0.072\%であるといわれる。わが国であその報告 例はすでに 120例以上に達している。

脺石をたは膵の石灰化の原因の主たるるのはア ルニール性, 内分泌性, 遺伝性のものであり，こ れ以外のものはあずらしいとのことである。わが 国の膵石症はアルコールに関係のあるものの他に 胆石症汇関係があると思われるるのも方る。 たこれらの症例の病歴に肺結核のみられるもの ああり，何らかの因果関係があるのではないかと る考光られる。楉病病との関俰については，著者 らが他 ${ }^{1)}$ 発表しているので，ここでは言及しな いが，本報告の中の第 1 例もいわゆる若年性糖尿 病であつた。

膵蔵のCa沈着の第 1 の型として膵実質の石灰 化がある。これは結石よりもその頻度は少ない。 Lagergrenによればhydroxy apatiteからなり燐酸 Caであるという。これが膵実質の脂肪壊死の部 分に沈着する．第 2 の型としての管腔内結石は主 として炭酸Caからなり,膵液分泌のうつ滞が遂に はCa沈着をきたすと考克られている。解剖学的 にはplugがまず見られ，つづいて，石灰化，管腔 の拡張，それにのら胞形成が見られるという。結 石はさらに膵管の部分的または完全閉塞をきた して結石の生成を助長することも考兄られる.

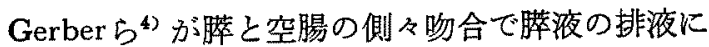
成功して症状の軽快や石灰化の消失をみたこと
は，このことと関連して興味ある所見である。

$\mathrm{X}$ 線像上に見られる比較的大きな結石は管腔内 結石であり， Gross ${ }^{57}$ とよれば遣伝性脺炎によくみ られる像であるとのことであり，本報告の 2 例も この型に相当する。るら一つのX線像で見られる 像は，び漫性のむのであり，多数の小さな管腔内 結石またはび漫性の管腔外の石灰化，それたこの 両者の混在しているるのを意味する。膵の石灰化 または脺石はX線で斜位をも加えての腹部単純撮 影といら非常に簡単な方法により診断が可能であ るが，その要点は，当然のことながら膵の位直す る部分にあることが先ず必要である。バリウムに よる胃・十二指腸，種々の方法で造影された胆の ら胆道との位置的な関係によつて推測される. 後 腹膜充気術に断層撮影を併用すればかなり確定的 となると思われる．注意すべきことは，前述のご とく結核との関係もあるためにリンハ節などの石 灰化との鑑別が必要である。しかし本報告例のご とく，一見して膵石としか考えようのないような 明らかな症例では疑点をさしはさむ余地がない。

さて，本報告の 2 例は家族性であることは姉妹 であることから間違いのない事実である。わが国 ではすでに 120例以上の膵石症例が報告されてい るが，著者の接し得た報告中に家族性といえるも のは，兄弟のかなり年長の大酒家にみられたわず か一組にすぎない，Grossらの報告では 5 組の遺 伝性脺炎が示されているが，遺伝性の膵炎は明ら かに稀なものである。しかし家族性といえるるの は単なる偶然で起るもの，例えばアルコールの過 飲，腹部外傷，食飭などの原因により同一家族の 複数例に起こるものがあり，このような例は実際 にはそれらしきすのも含めて何組か報告されてい る、例兊ばある自動車事故で腹部外傷後に革炎の 発生をみた 2 人の兄弟の例があげられている．勿 論，今な和，遺伝性膵炎としての診断基準が確立 しているわけではないが，同一家系に確実な膵炎 が3例以上なければかなりの疑いがのこるとされ る、さらには，その発症が比較的早い年代であ 
り, 先述のアルコールの過飲, 腹部外傷, 特別な 食慨というような原因となるべきすのみられな い症例では，その診断は比較的確実となる。本報 告の例では，その姉妹の册々一人の兄について腹 部単純撮影で膵石は見られなかつた。また，粹炎 としての典型的な病歷もなかつた。その家系の 他の構成員については調查はできていない，だか ら，現在この家采では 2 例しか脺石は発見されて いない。しかし，例数の不十分といらことを除け ば，その遺伝性の脺炎一膵石症としての条件は充 分に満足しているもの之考克てよい，勿論，膵炎 の確定診断としては膵石の存在，それも是方余地 のない比較的大きな膵管内の多数の結石がX線像 上で 2 例ともに確認されていること上り明らかで ある。すなわち本例は遺伝性膵石症といい得る症 例である。ただ第 2 例では痛みも明らかであり， 脺外分泌能も低下していることが証明されている が，第 1 例では痛みも明らかでなく，脺外分泌能 についても検查されていない。これに反して，第 1 例は若年性糖尿病として顕著な病像を示すが， 第 2 例はブドウ糖50g 経口負荷でhyper oxy型の 異常を示すのみである．遺伝性膵炎では先天的に 膵管の奇型があり管膑の狭小化を来たすことが， このような萃炎の原因と考劣られるとのことであ る. Grossらの報告の遺伝性粹炎 の確診例 22例中 16例とかなりの頻度に膵石が見られていること は，脺石の成因の第 1 に膵管の部分的または完全 な閉塞によるらつ滞があげられていることやこ
の遺伝性脺炎で脺石のあつた 2 例で手術的にうつ 滞をとり去ることにより，脺石の軽快をみたこと と考只合わせると興味がある。

最後に膵石と睟癌との関保については，すでに 他"》にのべたが，Grossらによれば，遺伝性膵炎の 症例中の 7 死亡例で 2 例の膵癌があり，そのいず れもが脺管内結石をもつていた症例であつたと報 告しているのも興味をひく問題である。

\section{おわりに}

22 才と 36 才の同一家族にみられた姉妹の膵石症 を報告した。妹例は18才㥧より若年性糖尿病とし ての顕著な症状で発症した．腹痛の病歴は明らか でなく，脺外分泌能も検查していない，姉例は10 才頃より腹痛をみとめ，膵外分泌能はパンクレオ ザイミン・セクレチン検査で 3 因子とも低下を示 していた．両例ともに腹部 $\mathbf{X}$ 線検查で膵に相当し て多数のかなり大きな結石を認めた，その発症が 若年であること、アルニールの飲酒歴がないこと， また，原因と考えられる外鹪などのないことより 遺伝性脺炎，ひいては遗伝性脺石症と診断してよ いと考える。

\section{文献}

1）堀内成人他：糖尿病投稿中. 一2）中西恒心他： 日消会誌. $64: 537,1967$. 一3) 乾久朗他：最新医 学, $19: 2202,1964 .-4)$ Gerber, B.C. et al.: Arch of Surg. $87: 70,1963 .-5)$ Gross, J.B. et al.: Ciba foundation symposium. on the exocrine pancreas. J. and A. Churchill, London. 1962, P 278，一6）北村次男他：成人病 $9: 17$, 1968 . 